\title{
molecules
}

ISSN 1420-3049

www.mdpi.com/journal/molecules

Communication

\section{Comparative Analysis of Click Chemistry Mediated Activity-Based Protein Profiling in Cell Lysates}

\author{
Yinliang Yang, Xiaomeng Yang and Steven H. L. Verhelst* \\ Lehrstuhl für Chemie der Biopolymere, Technische Universität München, Weihenstephaner Berg 3, \\ 85354 Freising, Germany; E-Mails: yinliangyang@gmail.com (Y.Y.); xiaomeng@hotmail.de (X.Y.) \\ * Author to whom correspondence should be addressed; E-Mail: verhelst@wzw.tum.de; \\ Tel.: +49-8161-713505; Fax: +49-8161-714404.
}

Received: 26 June 2013; in revised form: 7 August 2013 / Accepted: 26 September 2013 /

Published: 11 October 2013

\begin{abstract}
Activity-based protein profiling uses chemical probes that covalently attach to active enzyme targets. Probes with conventional tags have disadvantages, such as limited cell permeability or steric hindrance around the reactive group. A tandem labeling strategy with click chemistry is now widely used to study enzyme targets in situ and in vivo. Herein, the probes are reacted in live cells, whereas the ensuing detection by click chemistry takes place in cell lysates. We here make a comparison of the efficiency of the activity-based tandem labeling strategy by using $\mathrm{Cu}(\mathrm{I})$-catalyzed and strain-promoted click chemistry, different ligands and different lysis conditions.
\end{abstract}

Keywords: activity-based probes; cathepsins; click chemistry; proteases; protein modification

\section{Introduction}

Within chemical biology, site specific protein modification by covalent small molecule probes is a powerful and often used technique to interrogate biomolecular interactions and protein function. The introduction of covalent small molecule probes can be based on different types of chemistries: probes may be incorporated by the use of exogenous or endogenous enzymes [1,2], or they can contain an intrinsic reactivity such as an electrophile or photocrosslinker that by itself forms a covalent bond to the target proteins [3-5]. Generally, the probes can be dramatically adjusted in their selectivity by a combination of the reactive groups and additional structural elements that interact with the target proteins [6]. Activity-based protein profiling (ABPP) is a particularly interesting method, since it is 
able to address the functional state of a protein, i.e. active or inactive [3,4]. This is especially important for enzymes, which are dynamically regulated after translation. ABPP makes use of small molecules termed activity-based probes (ABPs) that are able to covalently tag active enzymes. ABPs generally consist of three elements: (1) a tag, (2) a reactive group that covalently reacts with a residue in the active site of the target enzymes, often in a mechanism-based way, and (3) a spacer with optional recognition elements that can induce selectivity. The method of detection of the modified proteins depends on the nature of the tag, such as a biotin or a fluorophore [7]. Most tags are relatively bulky compared with the small molecule probe, which influences the cell permeability and may prevent that the reactive group enters the active site. To circumvent these problems, two-step (tandem) labeling strategies using bioorthogonal reaction partners have been increasingly applied [8]. The 1,3-dipolar cycloaddition between azides and alkynes, commonly referred to as click chemistry $[9,10]$ has especially become popular. Since its introduction in tandem ABPP by Speers and Cravatt [11,12], azide or alkyne 'mini-tags' are now very common in activity-based probes (ABPs) and their applications in situ or in vivo (Figure 1) [13]. Several studies on the efficiency of the click reaction have been reported. Some have used fluorogenic click substrates, others metabolically labeled proteins, cell lysates or even whole cells or organisms for evaluation [14-17]. These studies have, for example, found out that some ligands for stabilization of the $\mathrm{Cu}(\mathrm{I})$ species lead to higher rates of cycloaddition than others.

Figure 1. Schematic representation of tandem ABPP as site specific and activity-based technique to covalently tag active enzymes in situ and in vivo. A small molecule ABP equipped with one partner of a bioorthogonal reaction pair forms a covalent bond with active site residues of a subset of enzymes in a cell. After lysis, tandem labeling, such as click chemistry, introduces a tagging moiety on the enzyme-ABP complex. Depending on the tag, different analysis methods can be used, such as in-gel scanning, or affinity enrichment with mass spectrometry detection.

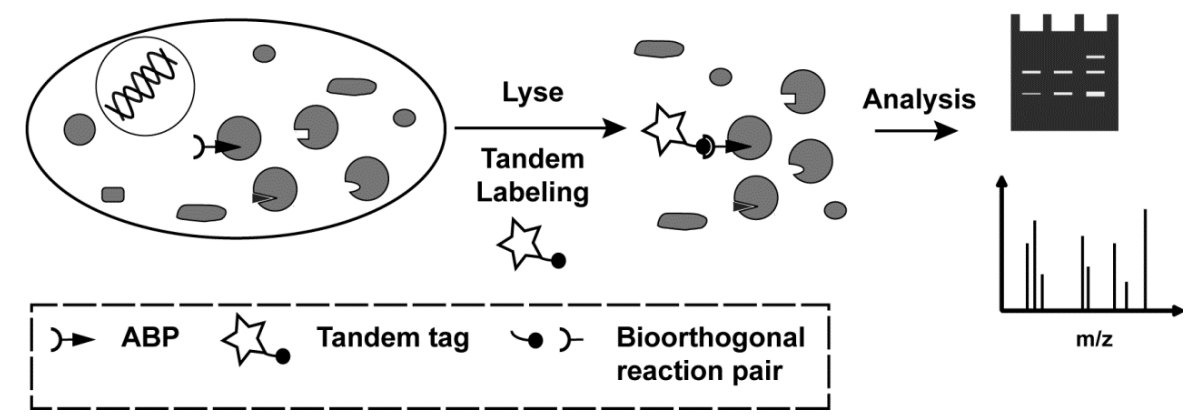

Unless detection in vivo or in intact cells is desired, such as in imaging, most tandem labeling in ABPP takes place in cell lysates. In this workflow, lysates, whole cells or organisms are first incubated with an ABP. Only after cells or tissues are lysed, click chemistry is performed and subsequent analysis takes place (Figure 1). One recent study has compared the usage of copper-free tandem labeling in ABPP (Staudinger ligation and strain-promoted click chemistry) [18]. However, not only the click reagents, but also the constituents of the lysate may have an influence on the tandem labeling efficiency. Therefore, we here report a comparative study on the efficiency of tandem labeling in ABPP using different click chemistry conditions and different lysis methods. 


\section{Results and Discussion}

\subsection{Activity-Based Probes and Fluorescent Tags}

In order to test the efficiency of click chemistry in ABPP, we used the cell permeable ABP azido-E-64 as a model probe [19] (1; Figure 2). It is based on the natural product E-64, which is a covalent inhibitor for cysteine proteases of the papain family [20]. Probe $\mathbf{1}$ is cell permeable and covalently modifies its target proteases at the active site cysteine. For in-gel detection of the ABP-protease complex we use fluorescent tags, since fluorescence provides high sensitivity and is easily detected by scanning wet gels. Hence, we selected two alkyne-containing fluorescent tags: the terminal alkyne $\mathbf{3}$ for $\mathrm{Cu}(\mathrm{I})$-catalyzed click chemistry, and the bicyclononyne (BCN) derivative $\mathbf{2}$ for $\mathrm{Cu}(\mathrm{I})$-free, strain-promoted click chemistry. The latter compound was synthesized in a one step procedure from a commercially available $\mathrm{BCN}$ derivative [21] with a short PEG linker and carboxy-tetramethylrhodamine succinimide ester.

Figure 2. The molecules used in this study: the cell permeable ABP azido-E-64 (1), two alkyne tags for click chemistry ( $\mathbf{2}$ and $\mathbf{3}$ ), and three ligands for $\mathrm{Cu}(\mathrm{I})$-catalyzed click chemistry.<smiles>CCOC(=O)[C@H]1O[C@H]1C(=O)N[C@@H](CC(C)C)C(=O)NCCCN</smiles>

1 Azido-E-64<smiles>[R]NC(=O)c1ccc(C(=O)[O-])c(-c2c3ccc(=[N+](C)C)cc-3oc3cc(N(C)C)ccc23)c1</smiles>

$2 \mathrm{R}=$ $3 \mathrm{R}$

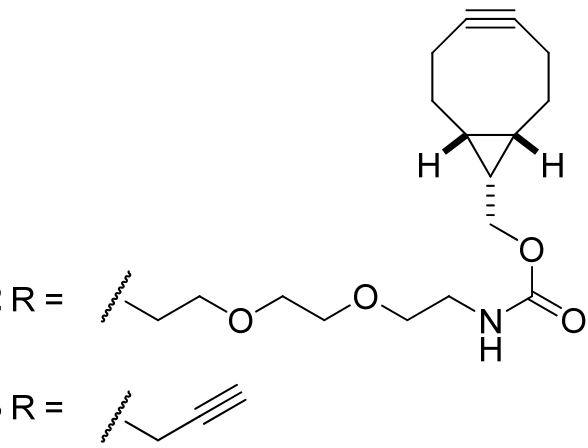<smiles>[R]n1cc(CN(Cc2cn([R])nn2)Cc2cn([R])nn2)nn1</smiles>
4 TBTA: $\mathrm{R}=\mathrm{Bn}$ 5 THPTA: $\mathrm{R}=\xi^{\xi} \mathrm{s}^{\xi} \mathrm{OH}$<smiles>CC(C)(C)n1cc(CN(Cc2cn(CC(=O)O)nn2)Cc2cn(C(C)(C)C)nn2)nn1</smiles>

Because $\mathrm{Cu}(\mathrm{I})$ is relatively instable in solution, click chemistry has benefited from ligands that chelate and stabilize $\mathrm{Cu}(\mathrm{I})$. The first reported ligand is the widely used tris[(1-benzyl-1H-1,2,3-triazol4-yl)methyl]amine (4; TBTA; Figure 2) [22]. This ligand was also the first ligand in tandem ABPP with click chemistry [11]. Other ligands such as THPTA (5) [14] and BTTAA (6) [15] have been developed to improve properties like water solubility. We here use these three ligands to compare their performance in the tandem ABPP. 


\subsection{Tandem Labeling Experiments}

To obtain a proteome with a small number of selectively azide-labeled proteins, we incubated the macrophage cell line RAW264.7 with $5 \mu \mathrm{M}$ azido-E-64 (1) for $1 \mathrm{~h}$. The main targets of azido-E-64 in this cell line are cathepsin $\mathrm{Z}$ and $\mathrm{B}$ in the molecular weight range of 26-30 $\mathrm{kDa}$ [23] (Figure 3a). After washing of the cells to remove free ABP, we performed lysis of the cells under different conditions (see section 2.2.2). As a negative control, DMSO vehicle treated cells were taken and subjected to the same lysis conditions. The resulting proteomes were subsequently used in the click chemistry labeling procedures.

\subsubsection{The Influence of Click Chemistry Reagents}

We first compared ligands 4-6 in the tandem tagging of the azide-labeled cathepsins with $\mathrm{Cu}(\mathrm{I})$-catalyzed click chemistry. Due to its limited solubility, TBTA (4) has been used as a ligand in ABPP at substoichiometric amounts with regard to the $\mathrm{Cu}^{+}$concentration $(50 \mu \mathrm{M}: 1 \mathrm{mM})[11,12]$. THPTA (5) and BTTAA (6) and can be used at much higher concentrations [14,15]. We here used 5 and 6 in either low $(50 \mu \mathrm{M})$ or high $(2 \mathrm{mM})$ concentration with a fixed $\left[\mathrm{Cu}^{+}\right]$of $1 \mathrm{mM}$. Although BTTAA (6) has shown higher kinetics of click chemistry in aqueous environment [15], we here do not observe a substantial difference in the intensity of the fluorescenly tagged cathepsins at $26-30 \mathrm{kDa}$ (Figure 3A; Figure S1). TBTA (4) performs only slightly worse than the other two (far left lane). The majority of the higher molecular weight bands as well as a band at approximately $22 \mathrm{kDa}$ are a result of background labeling independent of the presence of the azide-E-64 probe, as can be seen in the samples from DMSO treated control cells (Figure 3A; right panel). A higher ligand:copper ratio led to an overall lower amount of background. The intensity of target labeling, however, is not affected by the ligand:copper ratio.

In order to reduce the background, we decided to take a look at the influence of the alkyne reagent. A tenfold lower concentration of terminal alkyne $\mathbf{3}$ gave rise to a substantially lower background with similar intensties of the cathepsin bands (Figure 3B, left panel). Hence, a low concentration of alkyne tag seems beneficial for a detection with better signal to background ratio. In sharp contrast, strain-promoted click chemistry, which is a popular alternative to the copper catalyzed version, gave rise to very high non-specific staining (Figure 3B, right panel). This is most likely due to a thiol-yne reaction between cysteine containing proteins and the strained alkyne [15,24]. Lowering the concentration of the strained alkyne 2 to $5 \mu \mathrm{M}$ reduced the non-specific signals, but did not result in the clear cathepsin signals as observed with the $\mathrm{Cu}(\mathrm{I})$-catalyzed click reaction (Figure S2). Blocking the free cysteines prior to strain-promoted click chemistry has been reported to lower the thiol-yne background labeling [25]. Upon pre-treatment of the lysate with iodoacetamide, we indeed observed a lower amount of non-specific staining, and obtained clearer signals of target cathepsins (Figure 3B; right panel). Altogether, the $\mathrm{Cu}(\mathrm{I})$-catalyzed click reaction outperforms the strain-promoted one in the detection of labeled targets in cell lysates. These optimized conditions with an azide probe and a terminal alkyne tag show virtually identical labeling patterns compared with an alkyne probe and an azide tag (Figure S3), which was reported to give lower background [12]. 
Figure 3. (A) Comparison of the three different $\mathrm{Cu}(\mathrm{I})$ ligands for click chemistry. Cells were treated for $1 \mathrm{~h}$ with $5 \mu \mathrm{M}$ of probe 1, washed and lysed with $1 \% \mathrm{NP}-40$ in $100 \mathrm{mM}$ sodium phosphate $\mathrm{pH}$ 7.4. Lysates (diluted to $1 \mathrm{mg} / \mathrm{mL}$ total protein, $0.1 \% \mathrm{NP}-40$ final concentration) were incubated for $1 \mathrm{~h}$ with $1 \mathrm{mM} \mathrm{CuSO}_{4}, 1 \mathrm{mM}$ sodium ascorbate, $50 \mu \mathrm{M}$ or $2 \mathrm{mM}$ ligand and $50 \mu \mathrm{M}$ of the terminal alkyne tag 3. (B) Comparison of $\mathrm{Cu}(\mathrm{I})$-catalyzed and strain promoted click chemistry in lysates. Samples were treated similar as under (a) with THPTA as a ligand, but with different concentrations of the alkyne reagent. For strain-promoted click chemistry, only reagent $\mathbf{2}$ was added. Right panel: samples were pre-treated for $30 \mathrm{~min}$ with the indicated concentration of iodoacetamide (IA), then treated with strained alkyne $2(5 \mu \mathrm{M})$.
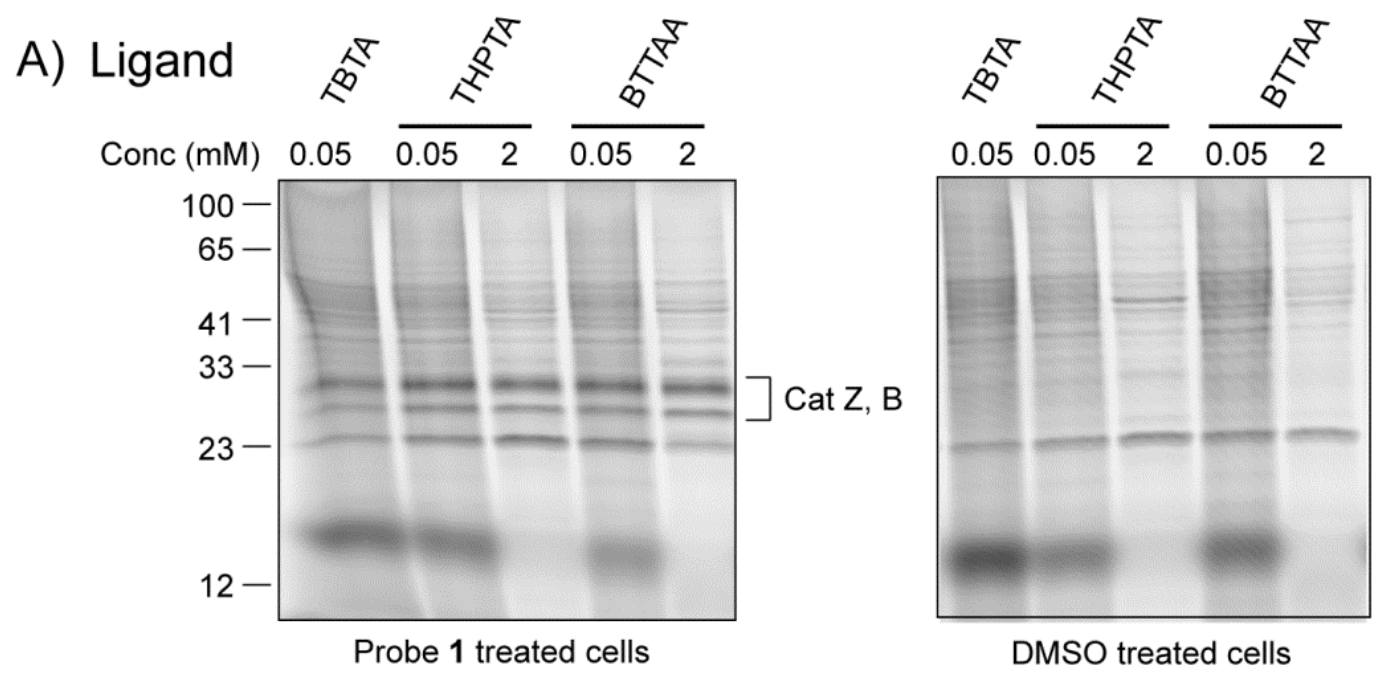

\section{B) Alkyne reagent}
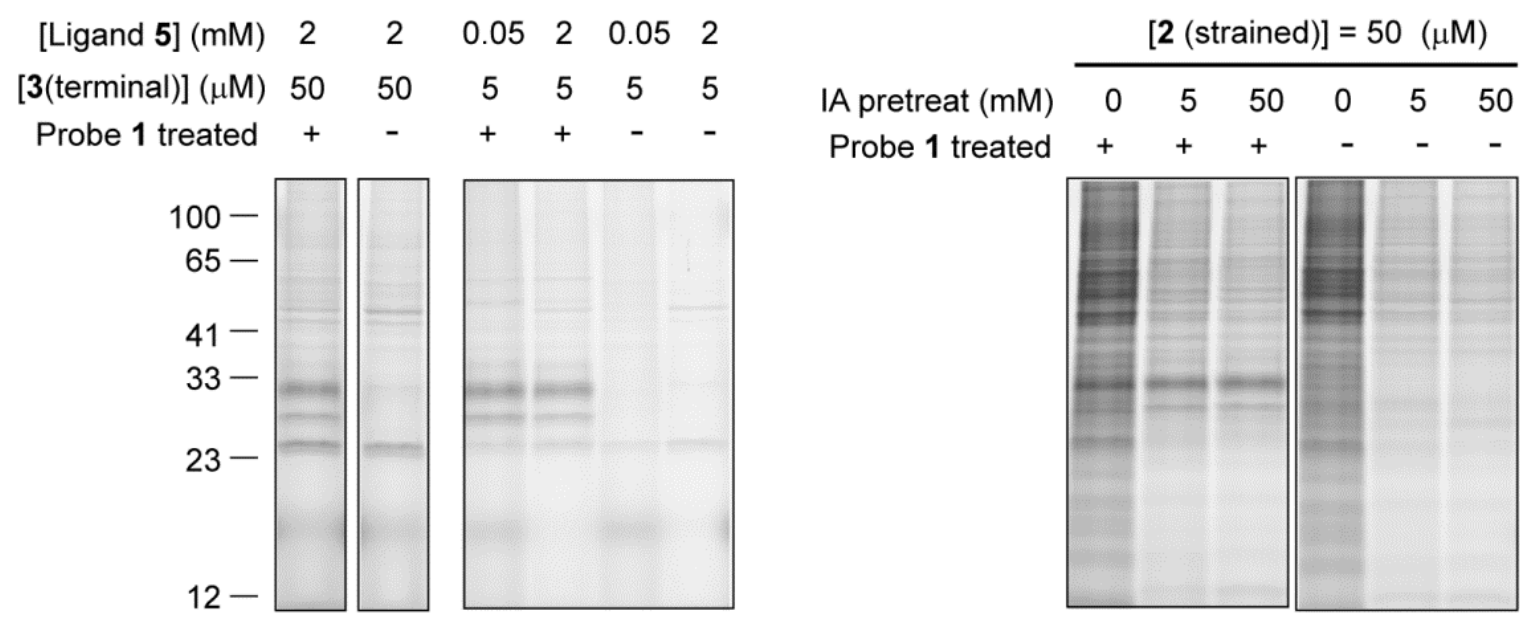

\subsubsection{The Influence of Lysis Conditions}

There are a wide variety of methods to make lysates from mammalian cells. Most make use of detergents to disrupt the cell membrane, while others use sonication or glass bead disruption. We have here used different lysis conditions to investigate the effect of buffer additives like detergents on the click chemistry efficiency (Figure 4A). High concentrations (1\%) of strong, ionic detergents like SDS 
or deoxycholate had a negative effect on the efficiency, as did the usage of high concentrations of urea. Dilution led to signals with higher intensity. Mild, non-ionic detergents did not show this dramatic effect. Detergent-free cell disruption using glass beads or sonication also gave low band intensities, possibly caused by worse solubilization of the cathepsin targets. Addition of SDS to these lysates also had a negative effect on the click chemistry.

We also investigated different buffering agents used in cell lysis buffers: sodium phosphate, Tris, HEPES, imidazole, tricine and citrate (Figure 4B). Both sodium phosphate and HEPES were compatible with the tandem ABPP labeling. Tris showed a decreased click chemistry efficiency, as it can act as an inhibitory ligand for the $\mathrm{Cu}(\mathrm{I})$ species [14]. A similar decrease was observed for imidazole, tricine and citrate buffers.

Figure 4. (A) Comparison of different lysis conditions on the tandem ABPP of cathepsins by $\mathrm{Cu}(\mathrm{I})$-catalyzed click chemistry. All buffers except RIPA contained $100 \mathrm{mM}$ sodium phosphate. SDS was added post lysis with glass beads. All protein concentrations were adjusted to $1 \mathrm{mg} / \mathrm{mL}$. Click chemistry was performed for $1 \mathrm{~h}$ with $5 \mu \mathrm{M}$ of alkyne 3,2 mM THPTA, $1 \mathrm{mM} \mathrm{CuSO}_{4}$, and $1 \mathrm{mM}$ sodium ascorbate. (B) Comparison of different buffering salts (all at $\mathrm{pH}$ 7.4; final detergent concentration $0.1 \%$ ) on the tandem ABPP of cathepsins.

A)

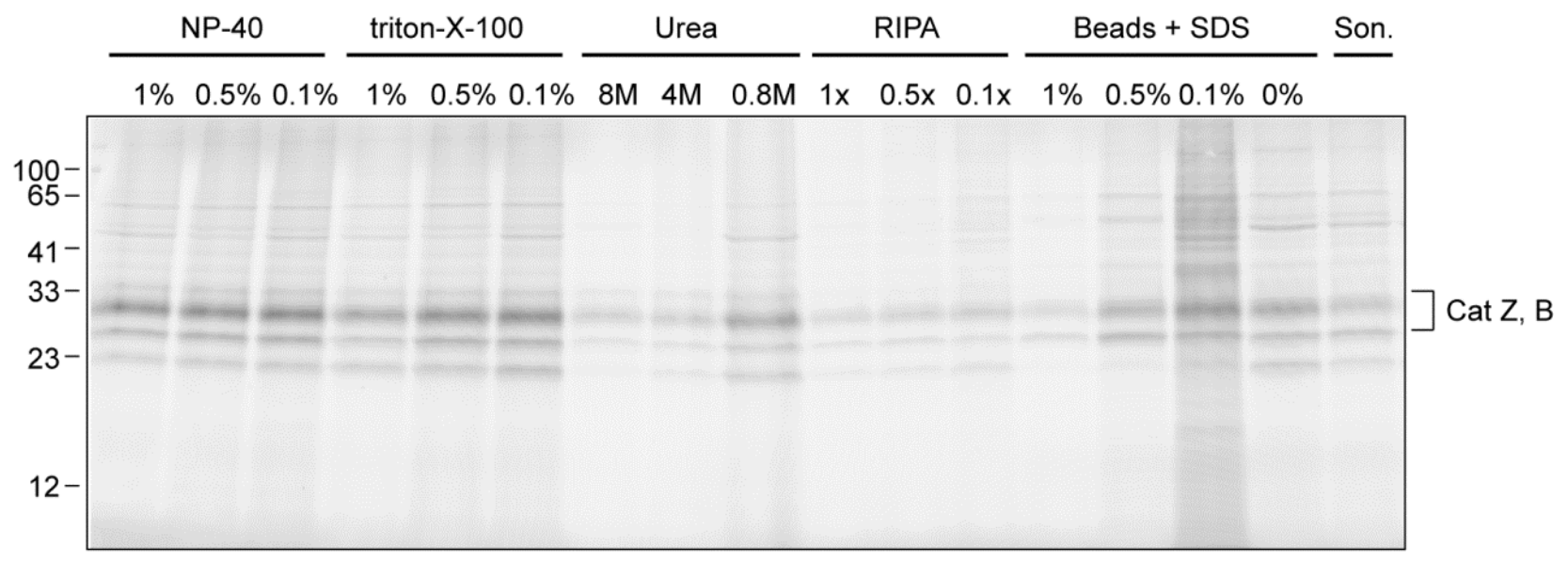

B)

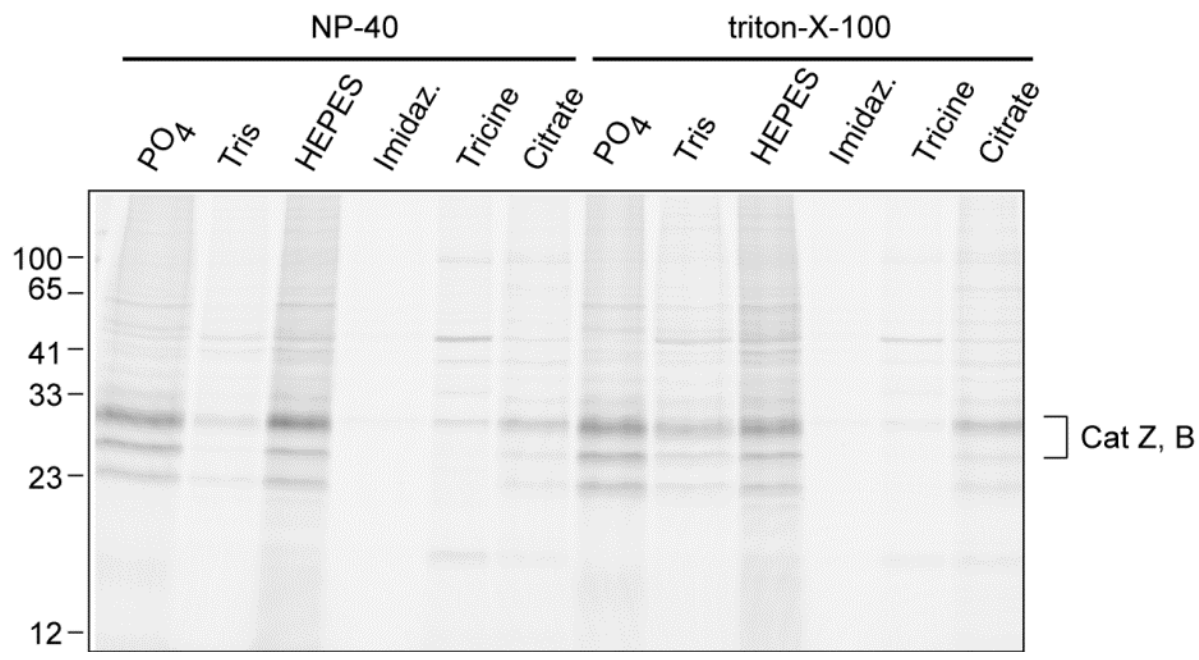




\section{Experimental}

\subsection{Materials}

$\mathrm{CuSO}_{4}$, propargylamine hydrochloride, diisopropylethylamine and bicyclo[6.1.0]non-4-yn-9ylmethyloxycarbonyl]-1,8-diamino-3,6-dioxaoctane were purchased from Sigma-Aldrich (Schnelldorf, Germany), NP40 substitute, Triton-X100, SDS, DMSO, HEPES, Tris, imidazole, tricine, citric acid and sodium deoxycholate were obtained from AppliChem (Darmstadt, Germany), sodium dihydrogenphosphate was purchased from Carl Roth (Karlsruhe, Germany), and 5- and 6-carboxytetramethylrhodamine, succinimidyl ester was received from Life Technologies (Darmstadt, Germany). TBTA [22], THPTA [14], azido-E-64 [19] were synthesized as reported. BTTAA [15] was a gift of the laboratory of Prof. Dr. Stephan Sieber (Technical University Munich, Department of Chemistry).

TAMRA-BCN conjugate 2: BCN-PEG-amine $(3.59 \mathrm{mg}, 0.011 \mathrm{mmol})$ was dissolved in DMSO $(400 \mu \mathrm{L})$. 5- and 6-carboxytetramethylrhodamine, succinimidyl ester $(4.86 \mathrm{mg}, 0.009 \mathrm{mmol})$ and DIEA $(1.93 \mu \mathrm{L}, 0.011 \mathrm{mmol})$ were added and the solution was incubated for $4 \mathrm{~h}$. The final product was purified by reversed phase HPLC to give a red compound (3.7 mg; yield 56\%). ESI-HRMS: $[\mathrm{M}+\mathrm{H}]^{+}$calculated for $\mathrm{C}_{42} \mathrm{H}_{48} \mathrm{~N}_{4} \mathrm{O}_{8} 737.3472$, found 737.3483.

TAMRA-propargylamine 3: 5- and 6-carboxytetramethylrhodamine, succinimidyl ester (3.2 $\mathrm{mg}$, $0.006 \mathrm{mmol})$ was dissolved in DMSO $(400 \mu \mathrm{l})$. Propargylamine hydrochloride $(1.2 \mathrm{mg}, 0.012 \mathrm{mmol})$ and DIEA ( $4 \mu \mathrm{L}, 0.023 \mathrm{mmol}$ ) were added and the solution was incubated overnight. The final product was purified by reversed phase HPLC to give a red compound (1.88 mg; yield 67\%). ESI-HRMS: $[\mathrm{M}+\mathrm{H}]^{+}$calculated for $\mathrm{C}_{28} \mathrm{H}_{25} \mathrm{~N}_{3} \mathrm{O}_{4} 468.1845$, found 468.1878 .

\subsection{Cell Culture and Generation of Lysates}

RAW 264.7 cells were cultured in DMEM medium containing 10\% heat-inactivated fetal bovine serum (FBS), 100 units $/ \mathrm{mL}$ penicillin, and $100 \mu \mathrm{g} / \mathrm{mL}$ streptomycin and maintained in a humidified $37{ }^{\circ} \mathrm{C}$ incubator with $5 \% \mathrm{CO}_{2}$. Cells with nearly $90 \%$ confluence were incubated for $1 \mathrm{~h}$ at $37{ }^{\circ} \mathrm{C}$ with fresh medium containing alkyne-E-64 (from a $5 \mathrm{mM}$ DMSO stock solution $(1000 \times$ ); final concentration of alkyne-E64: $5 \mu \mathrm{M}$; final DMSO concentration: 0.1\%). Next, cells were washed with PBS $(2 \times)$, harvested by using a cell scraper, collected by centrifugation, and lysed by the following methods: resuspension in $1 \%$ triton-X100 or 1\% NP-40 in either $50 \mathrm{mM}$ Tris pH 7.4, $50 \mathrm{mM}$ HEPES pH 7.4, $100 \mathrm{mM}$ sodium phosphate, $\mathrm{pH}$ 7.4, $50 \mathrm{mM}$ tricine, $\mathrm{pH}$ 7.4, $50 \mathrm{mM}$ imidazole, $\mathrm{pH}$ 7.4, or $50 \mathrm{mM}$ citric acid, $\mathrm{pH} 7.4$, and incubation on ice for $30 \mathrm{~min}$ (with vortexing every 10 minutes). The same was done for RIPA buffer $(50 \mathrm{mM}$ Tris, $150 \mathrm{mM} \mathrm{NaCl}, 1 \%$ triton-X100, $1 \%$ sodium deoxycholate, $0.1 \% \mathrm{SDS}, \mathrm{pH}$ 7.4). Incubation with $8 \mathrm{M}$ urea was followed by sonication. For lysates made with class beads, an equal volume of glass beads was added to the cell pellet together with detergent-free buffer. The mixture was vortexed for $30 \mathrm{~s}$, followed by incubation on ice for $1 \mathrm{~min}$. This process was repeated 3 times. For all lysis conditions, cell debris and unlysed cells were removed by centrifugation $(15,000 \mathrm{rpm})$ for 20 minutes. The supernatant was snap-frozen in liquid nitrogen and stored at $-80{ }^{\circ} \mathrm{C}$ until further usage. Protein concentrations were determined by Bradford or DC protein assay (Bio-Rad, Munich, Germany). 


\subsection{Bioorthogonal Labeling Reactions}

Azido-E-64-labeled proteome was diluted to $1 \mathrm{mg} / \mathrm{mL}$ total protein concentration with the appropriate buffer to obtain final detergent or additive concentrations as indicated. The click chemistry was carried out in a volume of $100 \mu \mathrm{L}$ For $\mathrm{Cu}(\mathrm{I})$-catalyzed tagging, the reaction mixture was incubated at room temperature for $1 \mathrm{~h}$ after the addition of $1 \mu \mathrm{L}$ of TAMRA-propargylamine $3(0.5 \mathrm{mM}$ or $5 \mathrm{mM}$ stock in DMSO), $1 \mu \mathrm{L}$ of ligand ( $5 \mathrm{mM}$ and $200 \mathrm{mM}$ stocks in DMSO), $2 \mu \mathrm{L}$ of sodium ascorbate ( $50 \mathrm{mM}$ stock in $\mathrm{H}_{2} \mathrm{O}$ ) and $2 \mu \mathrm{L}$ of $\mathrm{CuSO}_{4}\left(50 \mathrm{mM}\right.$ stock in $\mathrm{H}_{2} \mathrm{O}$ ). Note that the solutions of sodium ascorbate and $\mathrm{CuSO}_{4}$ were freshly made. For strain promoted click chemistry, the reaction mixture was incubated at room temperature for $1 \mathrm{~h}$ after the addition of $1 \mu \mathrm{L}$ of $2(0.5 \mathrm{mM}$ or $5 \mathrm{mM}$ stock in DMSO). For alkylation of the free thiols and subsequent labeling, the lysate was first incubated with iodoacetamide ( 5 or $50 \mathrm{mM}$ ) for $30 \mathrm{~min}$ followed by strain promoted click chemistry as described above. All reactions were stopped by adding $400 \mu \mathrm{L}$ of cold acetone and the mixture was stored at $-20{ }^{\circ} \mathrm{C}$ for $30 \mathrm{~min}$. After centrifugation $\left(15,000 \mathrm{rpm}, 4{ }^{\circ} \mathrm{C}, 20 \mathrm{~min}\right)$ the supernatant was removed and protein pellets were dissolved in $1 \mathrm{x}$ sample buffer $(132 \mu \mathrm{L})$. Thirty $\mu \mathrm{L}$ of this solution was separated by $15 \%$ SDS-PAGE. Gels were directly scanned on a Typhoon Trio+ $(\mathrm{PMT}=600)$. Gels were stained with Coomassie to check for equal protein loading.

\section{Conclusions}

Click chemistry is an important tool in bioorthogonal labeling of azide-functionalized biomolecules. Using tandem ABPP, we have evaluated the labeling efficiency in cell lysates as a function of different click chemistry conditions and different lysis methods. We were able to make several observations: (1) The nature of the ligand to stabilize the $\mathrm{Cu}(\mathrm{I})$ species did not have a substantial influence on the tandem labeling procedure in ABPP. Although differences in click chemistry kinetics have been reported for ligands 4-6, the $1 \mathrm{~h}$ incubation time and the conditions that were used in the tandem ABPP may have caused these differences to be less pronounced. Hence, we recommend the usage of $\mathbf{5}$ which is commercially available and can be used at a higher concentration than ligand $\mathbf{4}$, resuling in a lower background labeling. (2) Strain promoted click chemistry with fluorescent tag $\mathbf{2}$ gave rise to a high amount of background, consistent with earlier observations [18]. Although strained cyclooctynes have been successfully applied [26], for example in conjugations of purified biomolecules or in imaging of cell surface glycans, the usage in cell lysates is not advised. Lowering of the concentration of terminal alkyne tag 3 led to a decrease in background labeling, (3) The use of Tris, imidazole, tricine and citrate buffer gave lower click efficiencies than HEPES or phosphate buffer. The last two buffers are therefore preferred. (4) Strong, ionic detergents such as SDS and deoxycholate, influenced the tandem labeling in a negative way, as did the presence of high concentrations of urea. Thus, when possible, it is desirable to use mild, non-ionic detergents and dilute the lysate before click chemistry to lower the final detergent concentration.

\section{Supplementary Materials}

Supplementary materials can be accessed at: http:/www.mdpi.com/1420-3049/18/10/12599/s1. 


\section{Acknowledgments}

Funding was provided by the DFG (Emmy Noether program to SV), the Chinese Scholarship Council (fellowship to YY), and the Graduate Centre Weihenstephan of the Technische Universität München. We thank Georg Rudolf and Stephan Sieber for their kind gift of BTTAA, and Dieter Langosch for general support.

\section{Conflict of Interest}

The authors declare no conflict of interest.

\section{References}

1. Chen, I.; Ting, A.Y. Site-specific labeling of proteins with small molecules in live cells. Curr. Opin. Biotechnol. 2005, 16, 35-40.

2. Prescher, J.A.; Bertozzi, C.R. Chemistry in living systems. Nat. Chem. Biol. 2005, 1, 13-21.

3. Heal, W.P.; Dang, T.H.T.; Tate, E.W. Activity-based probes: Discovering new biology and new drug targets. Chem. Soc. Rev. 2011, 40, 246-257.

4. Cravatt, B.F.; Wright, A.T.; Kozarich, J.W. Activity-based protein profiling: from enzyme chemistry to proteomic chemistry. Annu. Rev. Biochem. 2008, 77, 383-414.

5. Geurink, P.P.; Prely, L.M.; van der Marel, G.A.; Bischoff, R.; Overkleeft, H.S. Photoaffinity Labeling in Activity-Based Protein Profiling. Top. Curr. Chem. 2012, 324, 85-113.

6. Haedke, U.; Kuttler, E.V.; Vosyka, O.; Yang, Y.; Verhelst, S.H.L. Tuning probe selectivity for chemical proteomics applications. Curr. Opin. Chem. Biol. 2013, 17, 102-109.

7. Sadaghiani, A.M.; Verhelst, S.H.L.; Bogyo, M. Tagging and detection strategies for activitybased proteomics. Curr. Opin. Chem. Biol. 2007, 11, 20-28.

8. Best, M.D. Click chemistry and bioorthogonal reactions: Unprecedented selectivity in the labeling of biological molecules. Biochemistry 2009, 48, 6571-6584.

9. Tornoe, C.W.; Christensen, C.; Meldal, M. Peptidotriazoles on solid phase: [1,2,3]-Triazoles by regiospecific copper(i)-catalyzed 1,3-dipolar cycloadditions of terminal alkynes to azides. J. Org. Chem. 2002, 67, 3057-3064.

10. Rostovtsev, V.V.; Green, L.G.; Fokin, V.V.; Sharpless, K.B. A stepwise huisgen cycloaddition process: Copper(I)-catalyzed regioselective "ligation" of azides and terminal alkynes. Angew. Chem. Int. Ed. 2002, 41, 2596-2599.

11. Speers, A.E.; Adam, G.C.; Cravatt, B.F. Activity-based protein profiling in vivo using a copper(I)-catalyzed azide-alkyne [3+2] cycloaddition. J. Am. Chem. Soc. 2003, 125, 4686-4687.

12. Speers, A.E.; Cravatt, B.F. Profiling enzyme activities in vivo using click chemistry methods. Chem. Biol. 2004, 11, 535-546.

13. Willems, L.I.; van der Linden, W.A.; Li, N.; Li, K.Y.; Liu, N.; Hoogendoorn, S.; van der Marel, G.A.; Florea, B.I.; Overkleeft, H.S. Bioorthogonal chemistry: applications in activity-based protein profiling. Acc. Chem. Res. 2011, 44, 718-729.

14. Hong, V.; Presolski, S.I.; Ma, C.; Finn, M.G. Analysis and Optimization of Copper-Catalyzed Azide-Alkyne Cycloaddition for Bioconjugation. Angew. Chem. Int. Ed. 2009, 48, 9879-9883. 
15. Besanceney-Webler, C.; Jiang, H.; Zheng, T.; Feng, L.; Soriano del Amo, D.; Wang, W.; Klivansky, L.M.; Marlow, F.L.; Liu, Y.; Wu, P. Increasing the efficacy of bioorthogonal click reactions for bioconjugation: A comparative study. Angew. Chem. Int. Ed. 2011, 50, 8051-8056.

16. Hong, V.; Steinmetz, N.F.; Manchester, M.; Finn, M.G. Labeling live cells by copper-catalyzed alkyne--azide click chemistry. Bioconjug. Chem. 2010, 21, 1912-1916.

17. Wang, W.; Hong, S.; Tran, A.; Jiang, H.; Triano, R.; Liu, Y.; Chen, X.; Wu, P. Sulfated ligands for the copper(I)-catalyzed azide-alkyne cycloaddition. Chem. Asian J. 2011, 6, 2796-2802.

18. van der Linden, W.A.; Li, N.; Hoogendoorn, S.; Ruben, M.; Verdoes, M.; Guo, J.; Boons, G.J.; van der Marel, G.A.; Florea, B.I.; Overkleeft, H.S. Two-step bioorthogonal activity-based proteasome profiling using copper-free click reagents: A comparative study. Bioorg. Med. Chem. 2012, 20, 662-666.

19. Hang, H.C.; Loureiro, J.; Spooner, E.; van der Velden, A.W.; Kim, Y.M.; Pollington, A.M.; Maehr, R.; Starnbach, M.N.; Ploegh, H.L. Mechanism-based probe for the analysis of cathepsin cysteine proteases in living cells. ACS Chem. Biol. 2006, 1, 713-723.

20. Barrett, A.J.; Kembhavi, A.A.; Brown, M.A.; Kirschke, H.; Knight, C.G.; Tamai, M.; Hanada, K. L-trans-Epoxysuccinyl-leucylamido(4-guanidino)butane (E-64) and its analogues as inhibitors of cysteine proteinases including cathepsins B, H and L. Biochem. J. 1982, 201, 189-198.

21. Dommerholt, J.; Schmidt, S.; Temming, R.; Hendriks, L.J.; Rutjes, F.P.; van Hest, J.C.; Lefeber, D.J.; Friedl, P.; van Delft, F.L. Readily accessible bicyclononynes for bioorthogonal labeling and three-dimensional imaging of living cells. Angew. Chem. Int. Ed. 2010, 49, 9422-9425.

22. Chan, T.R.; Hilgraf, R.; Sharpless, K.B.; Fokin, V.V. Polytriazoles as copper(I)-stabilizing ligands in catalysis. Org. Lett. 2004, 6, 2853-2855.

23. Yang, Y.; Hahne, H.; Kuster, B.; Verhelst, S.H.L. A simple and effective cleavable linker for chemical proteomics applications. Mol. Cell. Proteomics 2013, 12, 237-244.

24. Agard, N.J.; Baskin, J.M.; Prescher, J.A.; Lo, A.; Bertozzi, C.R. A comparative study of bioorthogonal reactions with azides. ACS Chem. Biol. 2006, 1, 644-648.

25. van Geel, R.; Pruijn, G.J.; van Delft, F.L.; Boelens, W.C. Preventing thiol-yne addition improves the specificity of strain-promoted azide-alkyne cycloaddition. Bioconjug. Chem. 2012, 23, 392-398.

26. Debets, M.F.; van Berkel, S.S.; Dommerholt, J.; Dirks, A.T.; Rutjes, F.P.; van Delft, F.L. Bioconjugation with strained alkenes and alkynes. Acc. Chem. Res. 2011, 44, 805-815.

(C) 2013 by the authors; licensee MDPI, Basel, Switzerland. This article is an open access article distributed under the terms and conditions of the Creative Commons Attribution license (http://creativecommons.org/licenses/by/3.0/). 